\title{
DESIGN AND PERFORMANCE EVALUATION OF AN ELECTRICALLY POWERED MULTI-PURPOSE FOOD ROASTER
}

\author{
Y. O. Ganiyu' ${ }^{1}$, M. O. Afolayan ${ }^{2, *}$ and S. O. Jolaiya ${ }^{3}$ \\ 1, 2, 3, MeChanical Engineering Department, Ahmadu Bello University, ZaRia, Kaduna State, NigERIA \\ E-mail addresses: 1 abuazim48@gmail.com, ${ }^{2}$ tunde_afolayan@yahoo.com, \\ 3 samojolaiya@gmail.com
}

\begin{abstract}
Food roasting is a method and technique used for transforming raw food into edible and tasty food accompanied with change or alteration in the appearance, taste, aroma, shape, or colour of the end product. The traditional method of use of open grill in Nigeria as an example, does not produce consistent end products. This work is about a multi-purpose roasting machine for Maize (Zea maize), Plantain (Musa paradisiaca) and Yam (Dioscorea Sagittifolia). The roasting temperature is allowed to vary between $160-240^{\circ} \mathrm{C}$ and the distance between the heat source and the item being roasted is also adjustable (50mm-150 $\mathrm{mm})$. A 10-50min experiment using ten maize cobs, yam slices and plantain of an average initial weight of $2.9 \mathrm{~kg}, 3 \mathrm{~kg}$ and $1.16 \mathrm{~kg}$ respectively led to $6.91 \%$, $6.7 \%$ and $9.5 \%$ weight loss and $68.4 \%, 66.1 \%$ and $94.1 \%$ roasting efficiency.
\end{abstract}

Keywords: Multi-Purpose, Food, Roasting, Roasting Conditions

\section{Nomenclature}

$\mathrm{B} L \quad$ total load on bearing $(\mathrm{N})$

d diameter of drilled holes $(\mathrm{mm})$

$\mathrm{D}_{\mathrm{FH}} \quad$ diameter for food housing $(\mathrm{mm})$

$\mathrm{d}_{\mathrm{i}} \quad$ diameter of chain roller $(\mathrm{mm})$

$D_{m h} \quad$ maximum hub diameter $(\mathrm{mm})$

$\mathrm{Dmv}_{\mathrm{mv}}$ maximum mean diameter of food item $(\mathrm{mm})$

Do outer diameter of Sprocket ( $\mathrm{mm})$

$\mathrm{E}_{\mathrm{E}} \quad$ electric motor efficiency (\%)

$E_{F} \quad$ energy required by the fan (J)

$\mathrm{E}_{\mathrm{HC}}$ power of the heating element (W)

EM impeller mechanical efficiency (\%)

Er roaster efficiency (\%),

FOS factor of safety

$\mathrm{H}$ plate thickness $(\mathrm{mm})$

$\mathrm{H}_{\mathrm{RC}} \quad$ roasting chamber height $(\mathrm{mm})$.

$\mathrm{H}_{\mathrm{RI}}$ inner height of roasting chamber $(\mathrm{mm})$

$\mathrm{H}_{\mathrm{RO}}$ outer height of roasting chamber $(\mathrm{mm})$

$\mathrm{K}$ multiplying factor

$\mathrm{k}_{1} \quad$ constant load factor

$k_{2}$ periodic lubrication factor

$\mathrm{k}_{3}$ continuous service conditions factor

$\mathrm{k}_{\mathrm{b}} \quad$ combined factor for bending $(\mathrm{Nm})$

ks service factor for the chain drive
$\mathrm{P}_{\mathrm{B}}$

$\mathrm{p}_{\mathrm{c}}$

PD

$P_{w}$

$r_{1}$

$\mathrm{R}_{2}$

$R_{c}$

$\mathrm{R}_{F H}$

$\mathrm{S}_{\mathrm{s}}$

$T$

$t$

$\mathrm{N}_{\mathrm{T}}$

$\mathrm{T}_{1}$

$\mathrm{T}_{2}$

$\mathrm{T}_{\mathrm{e}}$

It

v

$\mathrm{V}_{\mathrm{L} 1}$

$V_{1}$

$V_{L 2}$

$V_{2}$

$V_{3}$

$\mathrm{V}_{\mathrm{DH}}$ pressure exerted on the bearing $\left(\mathrm{N} / \mathrm{m}^{2}\right)$

pitch of the chain $(\mathrm{mm})$

pitch diameter for sprocket $(\mathrm{mm})$

power required by the fan (W)

inner radius $(\mathrm{mm})$

outer radius ( $\mathrm{mm}$ )

radius for inner constraint $(\mathrm{mm})$

radius for food housing cage $(\mathrm{mm})$

allowable stress $\left(\mathrm{N} / \mathrm{m}^{2}\right)$

motor torque $(\mathrm{Nm})$

maximum processing time (sec.)

number of teeth

number of teeth on driven sprocket

number of teeth on driving sprocket

equivalent twisting moment $(\mathrm{Nm})$

roaster insulation thickness $(\mathrm{mm})$

linear velocity $(\mathrm{m} / \mathrm{s})$

minimum linear velocity $(\mathrm{m} / \mathrm{s})$

volume of the vertical supports $\left(\mathrm{m}^{3}\right)$

maximum linear velocity $(\mathrm{m} / \mathrm{s})$

volume of side supports $\left(\mathrm{m}^{3}\right)$

volume of the front support $\left(\mathrm{m}^{3}\right)$

volume of drilled holes $\left(\mathrm{m}^{3}\right)$.

* Corresponding author, tel: +234 8053337523 


\begin{tabular}{|c|c|c|}
\hline $\mathrm{kt}_{\mathrm{t}}$ & combined factor for torsion & $V_{f}$ \\
\hline $\mathrm{L}$ & length of chain $(\mathrm{mm})$ & $V_{R}$ \\
\hline $\mathrm{LFH}_{\mathrm{FH}}$ & cylindrical food housing length (mm) & $V_{\text {RI }}$ \\
\hline $\operatorname{Imv}$ & $\begin{array}{l}\text { maximum mean value length of item being } \\
\text { roasted }(\mathrm{mm})\end{array}$ & $\begin{array}{l}\mathrm{V}_{\mathrm{RO}} \\
\mathrm{W}\end{array}$ \\
\hline LRC & roasting Chamber length $(\mathrm{mm})$ & $W_{B}$ \\
\hline LRI & inner length of roasting chamber ( $\mathrm{mm})$, & $W_{F}$ \\
\hline LRO, & outer length of roasting chamber & $W_{R C}$ \\
\hline L & specific latent heat $(\mathrm{kJ} / \mathrm{kg})$ & $W_{\text {RI }}$ \\
\hline M & bending moment $(\mathrm{Nm})$ & $W_{R O}$ \\
\hline $\mathrm{m}$ & mass $(\mathrm{kg})$ & Ws \\
\hline $\mathrm{m}_{1}$ & mass of roasted food $(\mathrm{kg})$ & $\mathrm{x}$ \\
\hline $\mathrm{m}_{2}$ & mass of unroasted food $(\mathrm{kg})$ & $\mu$ \\
\hline$M_{b}$ & Bending moment (Nm) & $\rho$ \\
\hline $\mathrm{Mt}_{\mathrm{t}}$ & Torsional moment (Nm) & $\sigma_{b}$ \\
\hline Mw & Mass of evaporated moisture content (\%) & $\sigma_{\text {ta }}$ \\
\hline $\mathrm{n}$ & number of food in row & $\mathrm{t}$ \\
\hline $\mathrm{N}_{\mathrm{S}}$ & speed of the pinion sprocket $(\mathrm{m} / \mathrm{s})$ & $\mathrm{Tu}$ \\
\hline $\mathrm{N}_{\mathrm{H}}$ & number of drilled holes & \\
\hline $\mathrm{P}$ & power (W or kW) & \\
\hline
\end{tabular}

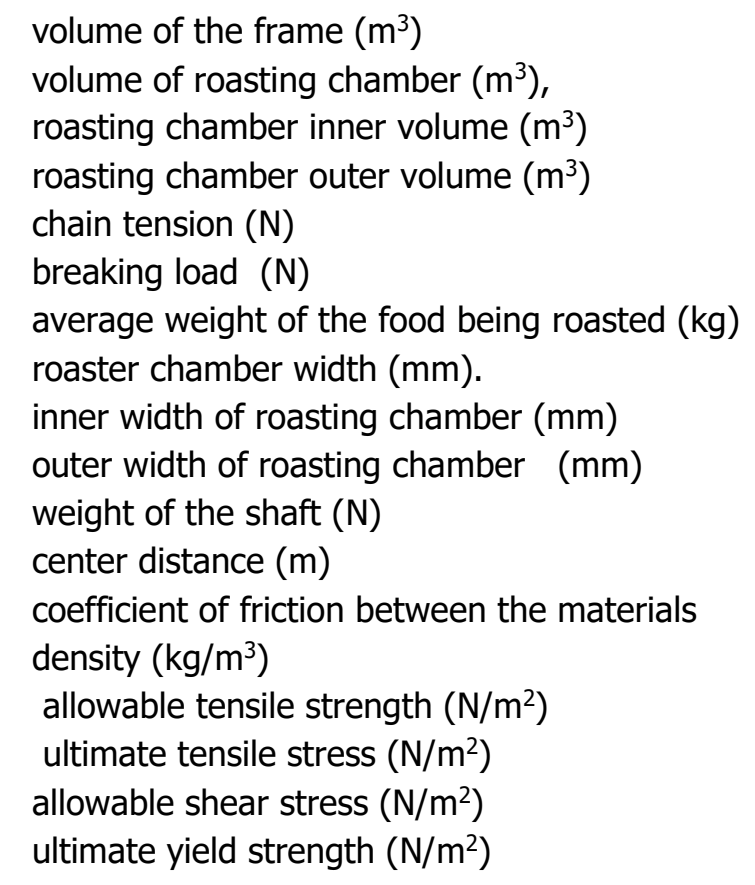

\section{INTRODUCTION}

The processing of food items has become an important aspect in human daily consumption of food. It is the methods and techniques used to transform raw ingredients into consumable food or a process by which a raw food is transformed to edible food for consumption by humans or animals either in the home or by the food processing industries [1]. This processing involves application of engineering technology with the aid of food science, to change or alter the appearance, taste, aroma, shape, or colour of the food. Various techniques are available for food processing, most of which are applied in the food industry. These techniques include size reduction, mixing [2] and processing by application of heat [3]. Generally, the size of food materials is often reduced during processing because it reduces the drying time or cooking time as more surface area is exposed to the hot air and gives rise to shorter drying or cooking time [4]. Roasting or grilling is a dry heat cooking process and is one of the most popular methods used for cooking foods. The roasting process tends to evaporate and reduce the moisture content of any type of food, shrinking the fibre and making the food tough [5].

Adisa[6] and Ezekiel et al., [7], designed and developed Charcoal Fired and electric heated Plantain (Musa Paradisiaca) roasting machine respectively. The result of the experiment carried out on the

roaster showed that plantain was roasted at $185^{\circ} \mathrm{C}$ for 21.16 minutes and PAHs concentration of $0.15 \mu \mathrm{g} / \mathrm{g}$ with $0.00 \mu \mathrm{g} / \mathrm{g}$ carcinogenic PAHs were obtained using charcoal fired plantain roaster while the evaluation made from the electric heated roaster was that the design took 32 minutes to attain its roasting temperature of $200^{\circ} \mathrm{C}$ from $30^{\circ} \mathrm{Catmospheric}$ temperature. Adegbola et al. [8] designed and constructed a domestic basic oven, which was tested with varieties of food item like fish, meat and egg. Oke [9] developed a manually operated multipurpose roasting charcoal fired roaster and evaluated and tested it with yam, plantain and maize cobs. He found that average roasting time was 15, 30 and 24 minutes in $95 \%, 97 \%$ and $94 \%$ of times respectively. Olayinka and Adegboye [10] obtained average roasting time for maize cobs and plantains as 12 minutes and 20 minutes respectively as compared to 15 minutes and 35 minutes for Yam and plantain using convectional roasting method.

Currently, roasting of common delicacies such as maize, plantain and sliced yam on the streets in Nigerian cities and townships have been done using traditional way of roasting, which is roasting over open fire or grill. Despite being very stressful, healthrisky and environmentally hazardous, it is still being used. The stress includes regular blowing of air to sustain combustion and regular changing of the position of the food product to prevent it from 
burning [11] and uneven circulation of heat. Furthermore, lack of appropriate knowledge and inconsistent roasting conditions such as roasting temperature, roasting time and roasting distance from the heat source is commonly observed $[12,13]$. The goal of this work is to present a design and performance evaluation of an electric powered multipurpose roaster for maize (Zea maize), ripe plantainMusa paradisiaca) and sliced yam (DioscoreaSagittifolia).

This work is essential as the livelihood of many families depends on this road side roasting business in Nigeria. The aforementioned hazards will also be reduced when enclosed roasting device is used for roasting.

\section{METHODOLOGY}

\subsection{Brief Description of the Developed Machine}

The device (figure 1) is a forced convection electrically powered multi-purpose food roaster, for roasting maize, ripe plantain and sliced yam. The external and internal body (the roasting chamber) is made of galvanized iron sheet owing to its resistance to rust or corrosion and does not contaminate the food substance being processed. Fiber wool is stuffed in between inner and outer galvanized sheets and acts to prevent loss of heat (insulation).The roasting chamber houses three cylindrical baskets that rotates with the aid of shaft through the chain drive mechanism. Two fans are installed (on the left and right sides) for forcing air movement. A Nichrome electric heating element is also installed below the baskets. A thermostat controls the temperature of the roasting chamber and installed fans aid circulation of heat in the chamber for homogenous roasting. The chamber is incorporated with chimney to expel moisture released from the food during roasting and a transparent observation window/door made from fiberglass.

\subsection{Design Considerations}

In the design of this multi-purpose food roaster, food under investigation is expected to rotate at constant speed to receive equal heat circulation and this actually eliminate manual changing of food position. Its design is based on the maximum mean values of maize length: $239 \mathrm{~mm}-273 \mathrm{~mm}$, diameter: $44.3 \mathrm{~mm}$ $48 \mathrm{~mm}$, weight: $181.6 \mathrm{~g}-408.6 \mathrm{~g}$ and plantain length: 181mm-200mm, diameter: 36mm-40mm, weight: $116 \mathrm{~g}$ peeled and $183 \mathrm{~g}$ unpeeled [14 and 15] and sliced yam with average thickness being $25 \mathrm{~mm}$ $50 \mathrm{~mm}$.

\subsection{Component Design}

The roasting chamber assembly, the frame or support and the prime mover assembly are considered to be critical for a successful roasting operation. The roasting chamber subassembly consists of the chamber itself, the transparent observation window, 3 cylindrical baskets and the recirculation fans. The frame is treated as a welded cubical body. Its ability to carry weight without failing was further simulated. The prime mover assembly consists of the electric motor, the chain, the sprocket and the shaft carrying the 3 rotating basket and the shaft bearing used in transmitting the torque to the 3 baskets.

\subsubsection{The roasting chamber and its accessories} The food basket is shown in Figure 1 with the diameter and length indicated as well. Their values are determined as follows;

(i) Diameter of the basket;

$$
D_{F H}=2 R_{F H}=2\left(D_{m v}+R_{c}+\text { clearance }\right)
$$

(ii) Its Length;

$$
L_{F H}=n l_{m v}
$$

The chamber (figure 2) houses the 3 baskets, fans and electric heating element. Its dimension is dependent on the dimensions of the basket, ends clearance and upper and lower clearance.

Width of Roasting Chamber;

$$
\begin{aligned}
W_{R C}=L_{F H}+2(\text { clearance }) & \\
& +2 \text { (insulation thickness) }
\end{aligned}
$$

Length of the roasting chamber;

$$
L_{R C}=3 D_{F H}+
$$

(Clearance between food baskets and the chamber wall + 2(insulation thickness)

Height of the roasting chamber; $\mathrm{H}_{\mathrm{RC}}$

$=\mathrm{D}_{\mathrm{FH}}+$ maximum roasting distance + upper clearance

+2 (insulation thickness)

Volume of Roasting Chamber; $\mathrm{V}_{\mathrm{R}}=\mathrm{V}_{\mathrm{RO}}-\left(\mathrm{V}_{\mathrm{RI}}+\mathrm{V}_{\mathrm{DH}}\right)(6)$

Outer volume; $V_{R O}=L_{R O} \times W_{R O} \times H_{R O}$

Inner volume; $\mathrm{V}_{\mathrm{RI}}=\mathrm{L}_{\mathrm{RI}} \times \mathrm{W}_{\mathrm{RI}} \times \mathrm{H}_{\mathrm{RI}}$

Volume of drilled holes [10]

$$
V_{D H}=\frac{\pi d^{2} I_{t}}{4} \times N_{H}
$$




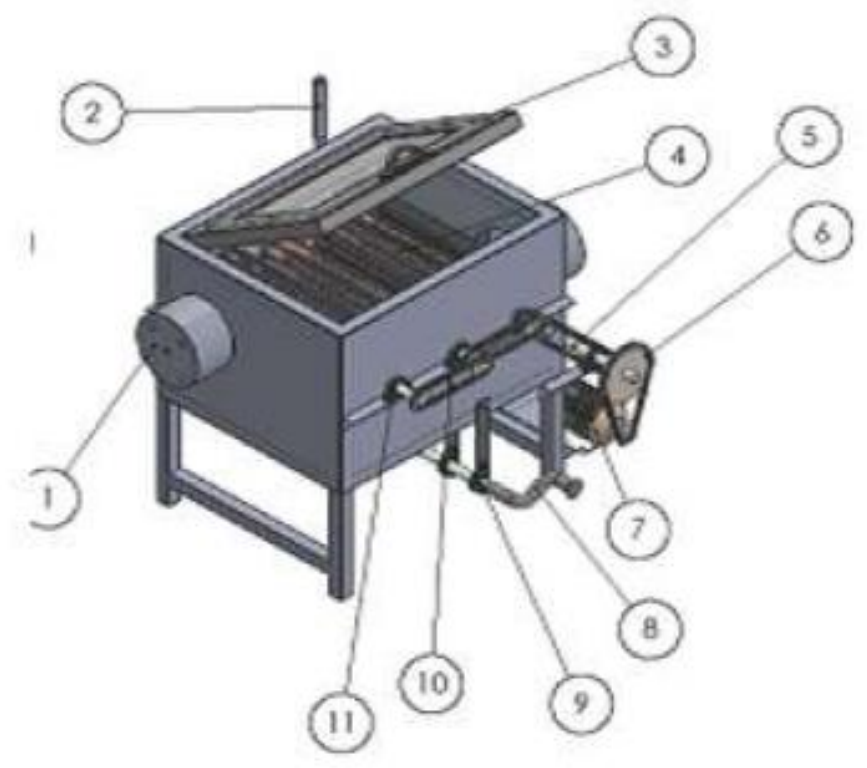

1 Fan housing

2 Chimney

3 Observation windows

4 Roasting basket (3 units)

5 Chain drives

6 Driving sprocket

7 Electric motor

8 Support and frame

9 Support

10 Chain drives to other roasting baskets

11 Roasting basket bearing

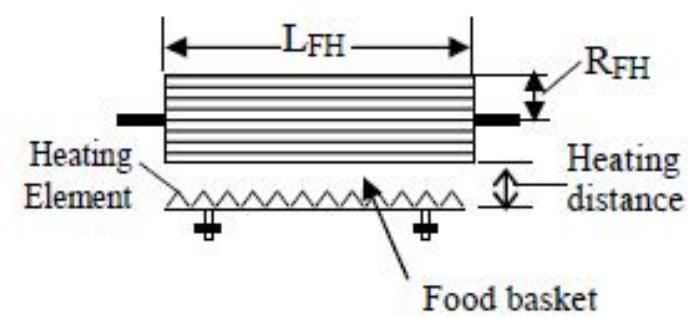

Fig. 1: The Developed Multipurpose Food Roasting Machine

\section{The Fan}

The energy required by the fan is given [16] as:

$$
E_{F}=\frac{P_{w t}}{E_{E} \times E_{M}}
$$

\section{The electric heating element}

The heating element was selected to be easily replaceable. A 1000watt Nichrome wire commonly used for open electric cooker was selected for supplying the heat needed for the roasting operations.

\subsubsection{The Frame}

The frame (Figure 3) consists of front support-3, side support-2 and vertical support-1.
Volume of the frame;

$\mathrm{V}_{\mathrm{f}}=\mathrm{V}_{1}+\mathrm{V}_{2}+\mathrm{V}_{3}$

The mass of the frame is given as

$$
m=\rho \times V_{f}
$$

Normal stress within the frame was deduced using Multi-Physics simulation tool. The maximum normal stress was found to be $16.42 \mathrm{MPa}$ and it occurs at the junctions marked $X$ in figure $4(A)$. The maximum displacement $(0.25 \mathrm{~mm})$ and the maximum shear stress (1.412 MPa) occurred at junctions marked $Z$ as shown in figure 4 (B). Most mild steel can take up these stresses without failing.

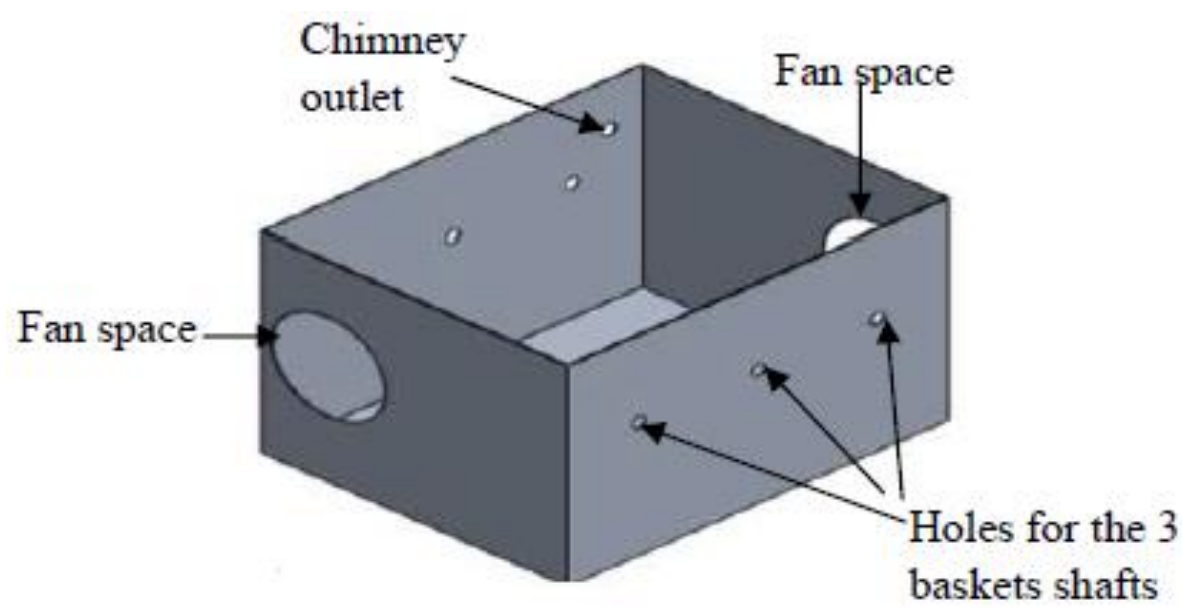

Figure 2: The Roasting Chamber 


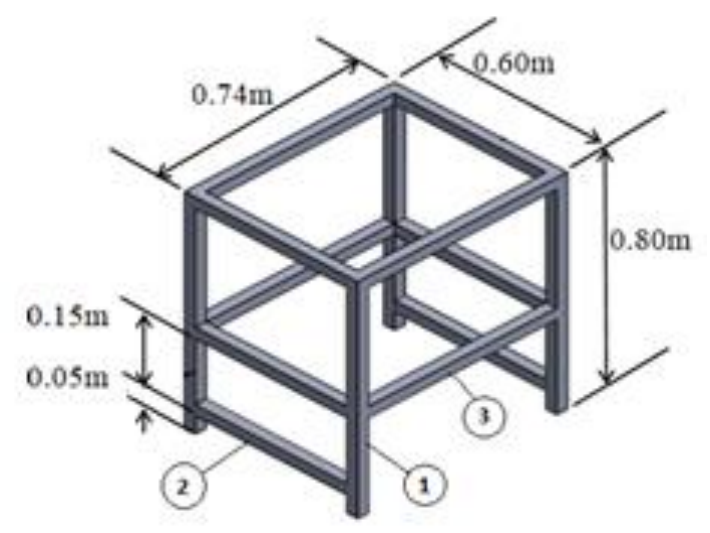

Figure 3: Machine Frame (dimension $800 \times 740 \times 600 \mathrm{~mm}$ )
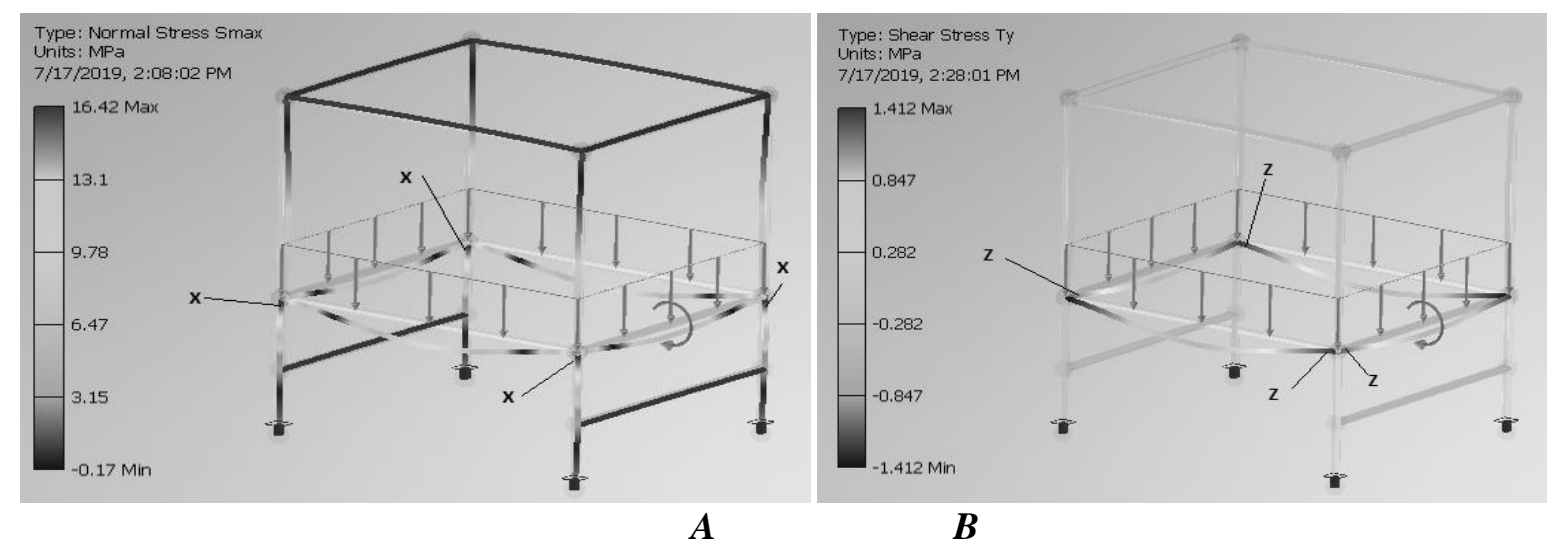

Figure 4 The normal stress $(A)$ and the shear stress $(B)$ within the frame.

\subsubsection{The Prime Mover}

\section{Sprocket Design and Selection}

The sprocket selection was made alongside with the minimum chain size of 35 with chain pitch $\left(p_{c}\right)$ of $9.52 \mathrm{~mm}$ and diameter $\left(\mathrm{d}_{\mathrm{i}}\right)$ of $5.1 \mathrm{~mm}$, number of teeth ( $T_{1}=32$ and $\left.T_{2}=16\right)$ and plain carbon steel material. The plate thickness is given as [17];

$D_{m h}=\operatorname{Cos}(180 /$ smaller number of teeth $) \times P D-$ $(\mathrm{H}+0.05)$

But, $\mathrm{PD}=$ Constant $\times$ Chain pitch $\left(\mathrm{p}_{\mathrm{c}}\right)$

Pitch Diameters (PD) for smaller and bigger sprocket at $T_{2}=16$ and $T_{1}=32$, Constant are 5.1259 for the driver and 10.2023 for the driven sprockets. Hence, for; smaller sprocket, $P D=48.9 \mathrm{~mm}$ and for bigger sprocket, PD $=97.23 \mathrm{~mm}$.

At sprocket plate thickness for selected number of tooth of $T_{2}=16$, the maximum hub diameter $D_{m h}$ is $37.7 \mathrm{~mm}$ according to [17].

The maximum bore diameter of $25.4 \mathrm{~mm}$ (that is $26 \mathrm{~mm}$ using standard shaft size) is suitable for the hub diameter between $48.85 \mathrm{~mm}$ and $97.23 \mathrm{~mm}$ according to [17] specification. Therefore, the bore diameter is considered as shaft diameter for the sprocket. Outer diameters of driving sprocket and driven sprocket at $T_{1}=32$, and $T_{2}=16$ respectively is given [18] as:

$D_{0}=P D+0.8 d_{i}$

\section{Chain System}

Chain power transmission has non uniform linear velocity and hence fluctuating velocity ratio, but varies from maximum to minimum during every tooth engagement (with the sprocket). This fluctuation in chain transmission is minimized by increasing number of teeth on the sprocket.

Maximum and Minimum linear velocities for the chain drive was computed using equation (15) and (16) given by [19] as;

$V_{L 2}=2618(P D) \operatorname{Cos} \frac{180}{T} N_{S}$

$V_{L 1}=2618(P D) N_{S}$

Since the chain pitch is between $12 \mathrm{~mm}$ and $15 \mathrm{~mm}$ and designed for low speed of 50rpm (i.e. less than 1 rotation per second), factor of safety for the chain 
drive is selected as 7as suggested by Khurmi and Gupta [19].

The power transmitted by the chain on the basis of breaking load $W_{B}$, is given by this relation [19];

$$
P=\frac{W_{B . V}}{F O S \cdot K_{S}}
$$

Where $K_{s}=K_{1} K_{2} K_{3} \quad W_{B}=10.6 p_{c}$ and $\mathrm{FOS}=7$ The constant load, periodic lubrication and continuous service conditions for chain drive were considered for design. In that scenario, $\mathrm{K}_{1}=1, \mathrm{~K}_{2}=1.5$ and $\mathrm{K}_{3}=1.5$ according to Khurmi and Gupta [19]. From [17], $\mathrm{p}_{\mathrm{c}}=9.52$ and $\mathrm{v}=10.5$ (from equation16) and hence $\mathrm{K}_{s}=2.25$ and $\mathrm{P} \approx 70 \mathrm{~W}$.

Therefore, a 70Watts $(0.1 \mathrm{Hp})$ electric motor will be capable of running the roaster mechanism.

The chain tension (W) on driving side according to Khurmi and Gupta [19] is given as

$$
W=\frac{W_{B}}{F O S}
$$

The length of the chain is also given as shown in equation (19)

$$
L=K p_{c}
$$

Where

K

$=\frac{T_{1}+T_{2}}{2}+2 m$

$+\frac{\left[\operatorname{cosec}\left(\frac{180^{\circ}}{T_{1}}\right)-\left(\operatorname{cosec}\left(\frac{180^{\circ}}{T_{2}}\right)\right]^{2}\right.}{4 m}$

and $m=\frac{x}{p_{c}}$

Where $x=2 R_{F H}+$ distance between each of the roasting baskets $=200 \mathrm{~mm}$

(The distance between each of the roasting basket is $50 \mathrm{~mm})$.

To accommodate initial sag in the chain, the value of center distance was increase by $5 \mathrm{~mm}$ (in practice, it is made physically adjustable between 2 and $5 \mathrm{~mm}$ ), thus $m=24.475, K=72.922 \mathrm{~mm} \cong 73 \mathrm{~mm}$ and $\mathrm{L}$ $=694.22 \mathrm{~mm} \cong 700 \mathrm{~mm}$. The chain length used for power transmission from one sprocket to another will be $70 \mathrm{~cm}$.

\section{The Shaft}

The critical shafts are those bearing the three food baskets. The diameter of the shafts for the sprockets is already determined as $26 \mathrm{~mm}$ (for each of the three food baskets) as being equal to the sprocket bore diameter. These shafts are subjected to fluctuating torque and bending moments. Lateral loading is not pronounced. We need to find out if the selected diameter of the shaft $(26 \mathrm{~mm})$ made from mild steel material will safely carry the load. We also need to take cognizance of the combined shock and fatigue factors.

According to Hall et al. [20], the diameter expected of the shaft to bear such load is given as;

$$
d_{o}^{3}=\frac{16}{\pi S_{s}} \sqrt{\left(K_{b} M_{b}\right)^{2}+\left(K_{t} M_{t}\right)^{2}}
$$

where

$$
M_{t}=\frac{9550 \times P}{r e v / \min } \quad \mathrm{Nm}
$$

and

$$
M_{b}=\sqrt{M_{y}^{2}+M_{z}^{2}} \quad N m
$$

From Figure $5, \mathrm{My}_{\mathrm{y}}$ is due to the distributed weight of the basket with food item $=-3.03 \mathrm{~N}-\mathrm{m}$ and $\mathrm{Mz}$ due to the chain tension $(19.23 \mathrm{~N})$ obtained from equation $(18)=-1.87 \mathrm{~N}-\mathrm{m}$. Also, in accordance to ASME standard, $\mathrm{S}_{\mathrm{s}}$, the allowable stress, is $55 \mathrm{~N}-\mathrm{mm}^{2}$ (with no keyway present). For gradually applied load for shaft already rotating, $\mathrm{K}_{\mathrm{b}}$ is 1.5 and $\mathrm{K}_{\mathrm{t}}$ is 1.0 . Power being transmitted, $\mathrm{P}$ is $0.07 \mathrm{~kW}$ (equation 17 ) at a rotational speed of $50 \mathrm{rev} / \mathrm{min}$. Hence $\mathrm{Mt}_{\mathrm{t}}=13.37 \mathrm{Nm}$ $(13370 \mathrm{~N}-\mathrm{mm})$ and $\mathrm{Mb}=3.56 \mathrm{Nm}(3560 \mathrm{~N}-\mathrm{mm})$

Bearing Selection: Rated loads and life of the bearings are the two basic factors commonly considered in any bearing selection. According to Spotts et al. [21], load on ball bearing ( $\mathrm{BL}_{\mathrm{L}}$ (which is what we intend to use) is determined using equation (24).

$$
\begin{aligned}
P_{B} & =\frac{B_{L}}{\pi\left(R_{2}-r_{1}\right)\left(R_{2}+r_{1}\right)} \\
\text { and, } \quad & B_{L}=W+W_{S}+W_{F}
\end{aligned}
$$

The outer and inner diameters of the ball bearing are $20 \mathrm{~mm}$ and $16 \mathrm{~mm}$ respectively as selected and length of the shaft, $L_{s}=W_{R C}+2 t_{\text {insulation thickness }}+$ $2 t_{\text {sprocket thickness }}=0.66 \mathrm{~m}$ $W_{s}=m g=\rho\left(\frac{1}{3} \pi r^{2} L_{s}\right) \cdot g=8.53 \mathrm{~N}$ and $\mathrm{W}_{\mathrm{F}}=23.1 \mathrm{~N}$. $\rho$ is assumed to be $7800 \mathrm{~kg} / \mathrm{m}^{3}$ [10].

(These values are for maximum quantity of either maize or yam or plantain that can be loaded into the roasting basket at a time; maize $=2.9 \mathrm{~kg}$, yam slices $=3 \mathrm{~kg}$ and plantain $=1.16 \mathrm{~kg}$ ).

From equation (18) and (25), $\mathrm{B}_{\mathrm{L}}=50.86 \mathrm{~N}$ and from equation (24), $\mathrm{P}_{\mathrm{B}}=0.353 \mathrm{~N} / \mathrm{mm}^{2}$

Also, the force to overcome friction [21]; $\mathrm{F}_{\mathrm{T}}$ is given as

$F_{T}=\frac{2}{3} \pi \mu P\left(R_{2}^{3}-r_{1}^{3}\right)$

The calculated design parameters (from equations 1 to 26) are shown in Table 1 with remarks. These 
values were used for the constructed multipurpose food roaster presented in this work.

\section{PERFORMANCE EVALUATION}

\subsection{Roasting Procedures}

Fresh harvested and matured maize, ripe plantain and yam were obtained from Samaru Market, Zaria, Kaduna State, Nigeria. The roaster was used to roast 10 maize cobs of average weight of $3.0 \mathrm{~kg}, 10$ peeled plantain fingers of $1.2 \mathrm{~kg}$ and 10 yam slices of $1.62 \mathrm{~kg}$ as initial weights before roasting. Then, each item was roasted using roasting temperature range of $160^{\circ} \mathrm{C}-240^{\circ} \mathrm{C}$, roasting time of $10-50 \mathrm{mins}$ and roasting height (from the electric heating element) of $50-150 \mathrm{~mm}$.Mass of each food were verified after roasting to ascertain percentage moisture loss using equation (27) given by [22].

$M_{w}=\frac{m_{2}-m_{1}}{m_{2}} \times 100(\%)$

\subsection{Efficiency of the Roaster}

Roasting efficiency based on percentage moisture evaporated from roasted food was verified using equation (28). The efficiency of the roaster is considered at optimal roasting parameters for each food.

$$
E_{r}=\frac{M_{w}-L}{E_{H C} \times E_{F}}
$$

\section{RESULTS AND DISCUSSIONS}

The designed multi-purpose food roaster was fabricated and assembled as shown in Figure 1. The experiments were carried out on maize cobs, sliced yam and plantain of initial average weights of $2.9 \mathrm{~kg}$, $3 \mathrm{~kg}$ and $1.16 \mathrm{~kg}$ at optimal roasting conditions of $160^{\circ} \mathrm{C}, 11 \mathrm{~min}$ and $150 \mathrm{~mm}, 186^{\circ} \mathrm{C}, 38 \mathrm{~min}$ and $149 \mathrm{~mm}$, and $220^{\circ} \mathrm{C}, 36 \mathrm{~min}$ and $138 \mathrm{~mm}$ for maize cobs, yam slices and plantain respectively. The optimum conditions (shown in figures 6, 7 and8) were arrived at using response surface methodology (RSM) using Design Expert ${ }^{\circledR}$ Software. The experimental data were the range of data (e.g. roasting temperature range of $160^{\circ} \mathrm{C}$ to $240^{\circ} \mathrm{C}$ ) input into the software.

For maize, the percentage moisture loss was calculated as $6.90 \%$ and its roasting efficiency as $68.4 \%$. For the sliced yam it was $6.67 \%$ and with a roasting efficiency of $66.1 \%$. For the plantain, the percentage moisture loss is $9.48 \%$ and roasting efficiency of $94.11 \%$. Compared to the existing traditional food roaster, which took 21 minutes roasting time with $60 \%$, 46minutes roasting time with $65 \%$ and 35 minutes roasting time with $63 \%$ [8]. In addition, Adisa [23] and Ezekiel et al. [6] took 21.16 minutes and 32 minutes to roast 10 fingers of plantain at $185^{\circ} \mathrm{C}$ and $200^{\circ} \mathrm{C}$ respectively while 12 minutes and 20 minutes were used by Olainka and Adegboye[9] to roast 10 maize cobs and 10 fingers of plantain. These results shows that there is a significant improvement on the performance of the developed multipurpose food roaster over the traditional and existing food roasting machine because important roasting conditions to predict best roasting qualities were considered in the design and experiment which were absent from the existing design used in comparison.

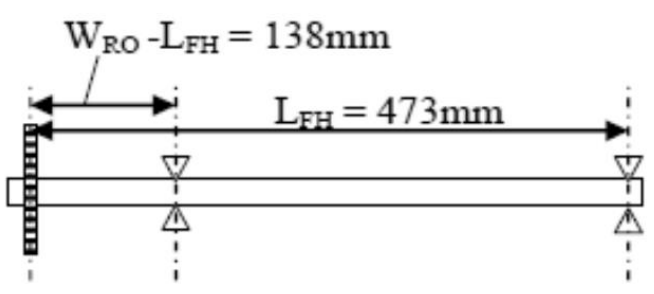

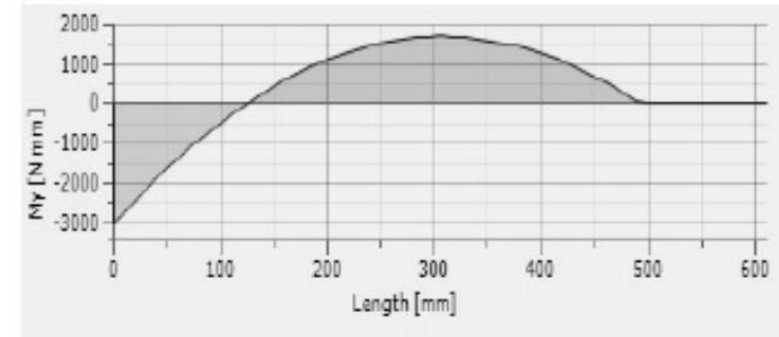

Maximum: $\mathrm{M}_{\mathrm{y}}-3030.72 \mathrm{~N}-\mathrm{mm}=-3.03 \mathrm{~N}-\mathrm{m}$

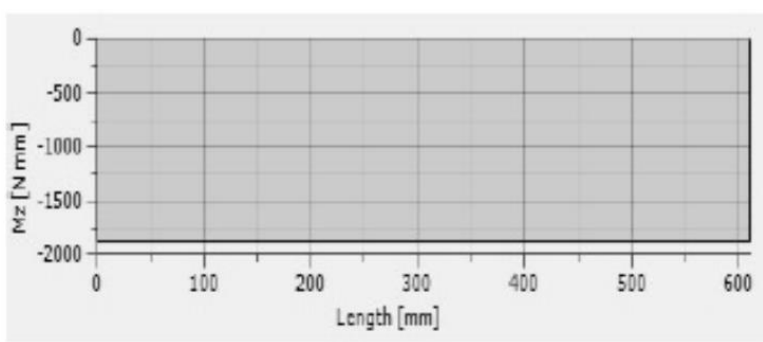

Maximum: $\mathrm{M}_{\mathrm{z}}-1869.730 \mathrm{~N}-\mathrm{mm}=-1.87 \mathrm{~N}-\mathrm{m}$

Fig. 2: Bending Moment Diagram 
Table 1 - The design parameters as used for the multipurpose food roaster

\begin{tabular}{|c|c|}
\hline Parameter & Remark \\
\hline $\mathrm{D}_{\mathrm{FH}}=170 \mathrm{~mm}$ & $D_{m v}=44 m m, R_{c}=36 \mathrm{~mm}$ and clearance $=$ of $5 \mathrm{~mm}$ \\
\hline \multicolumn{2}{|l|}{$\mathrm{LFH}_{\mathrm{FH}}=473 \mathrm{~mm}$} \\
\hline $\mathrm{W}_{\mathrm{RC}}=611 \mathrm{~mm}$ & $\begin{array}{l}\text { Width clearance of the roaster is } 54 \mathrm{~mm} \text { at each end and optimal thickness of } \\
\text { insulation is } 0.015 \mathrm{~m}(15 \mathrm{~mm})\end{array}$ \\
\hline$L_{R C}=740 \mathrm{~mm}$ & Distance in between food baskets is $50 \mathrm{~mm}$ \\
\hline $\mathrm{H}_{\mathrm{RC}}=402 \mathrm{~mm}$ & Maximum roasting distance $=150 \mathrm{~mm}$, upper clearance $=52 \mathrm{~mm}$ \\
\hline \multicolumn{2}{|l|}{$\mathrm{V}_{\mathrm{RO}}=0.182 \mathrm{~m}^{3}$} \\
\hline$V_{D H}=0.003 m^{3}$ & For 6 holes \\
\hline \multicolumn{2}{|l|}{$V_{R}=0.026 \mathrm{~m}^{3}$} \\
\hline$\left.E_{F}=45.6\right]$ & $\begin{array}{l}\text { Maximum roasting time }=50 \text { minutes, } \mathrm{E}_{\mathrm{E}} \text { and } \mathrm{E}_{\mathrm{M}}=50 \% \text { each } \\
\text { (the name plate specification for the fan selected is } 12 \mathrm{~cm} \text { diameter blade, } \\
210 \mathrm{~m}^{3} / \mathrm{h} \text { flow, } 220 \mathrm{~V}, 50 \mathrm{~Hz}-\mathrm{AC}, 2,300 \mathrm{rpm}, 0.22 \mathrm{~m}^{2} \text { area, } 38 \mathrm{~W} \text { ). }\end{array}$ \\
\hline$V_{f}=0.00226 m^{3}$ & $\begin{array}{l}V_{1}=0.00072 \mathrm{~m}^{3} \text { for } 4 \text { pieces, } \quad V_{2}=0.00100 \mathrm{~m}^{3} \text { for } 6 \text { pieces and } V_{3} \\
=0.00054 \mathrm{~m}^{3} \text { for } 4 \text { pieces }\end{array}$ \\
\hline $\mathrm{m}=17.63 \mathrm{~kg}$ & Using $\rho$ of $7,800 \mathrm{~kg} / \mathrm{m}^{3}$ (according to $[10]$ ), \\
\hline $\mathrm{H}=10.21 \mathrm{~mm}$ & $D_{m h}=37.7$ according to $[17]$ \\
\hline $\mathrm{D}_{0}=101.31 \mathrm{~mm}$ & for $T_{1}=32$ \\
\hline$=52.98 \mathrm{~mm}$ & for $T_{2}=16$ \\
\hline \multicolumn{2}{|l|}{$\mathrm{V}_{\mathrm{L} 1}=10.7 \mathrm{~m} / \mathrm{s}$} \\
\hline \multicolumn{2}{|l|}{$V_{\mathrm{L} 2}=10.5 \mathrm{~m} / \mathrm{s}$} \\
\hline $\mathrm{P} \approx 70 \mathrm{~W}$ & Power transmitted based on $\mathrm{W}_{\mathrm{B}}$ \\
\hline$W=14.42 \mathrm{~N}$ & Chain tension (W) on driving side \\
\hline $\mathrm{L}=70 \mathrm{~cm}$ & The chain length used for power transmission from one sprocket to another \\
\hline $\mathrm{d}_{\mathrm{o}}=11 \mathrm{~mm}$ & $M_{t}=13.37 \mathrm{Nm}, M_{b}=3.56 \mathrm{Nm}$ \\
\hline \multicolumn{2}{|l|}{$L_{s}=0.66 \mathrm{~m}$} \\
\hline \multicolumn{2}{|l|}{$\mathrm{B}_{\mathrm{L}}=50.86 \mathrm{~N}$} \\
\hline \multicolumn{2}{|l|}{$P_{B}=0.353 \mathrm{~N} / \mathrm{mm}^{2}$} \\
\hline $\mathrm{FT}_{\mathrm{T}}=866.01 \mathrm{kN}$ & $\begin{array}{l}\text { (with } \mu=0.3 \text { for steel }[21] \text { ), this is the minimum rating for the bearing to be } \\
\text { used }\end{array}$ \\
\hline
\end{tabular}

\section{CONCLUSION}

A multi-purpose roasting machine presented in this work has been designed and built in accordance to the design specifications. It was evaluated and the result of the evaluation compared well with other researchers results. Maize roasting is $68.4 \%$ efficient, Yam, $66.1 \%$ efficient and Plantain had a roasting efficiency of $94.11 \%$.

\section{REFERENCES}

[1]. Manuela, R. R; Chiara C; Cecilia C; Patrizia R; Carlo B; Barbara S and Erica L., 2012. Further Tool to Monitor the Coffee Roasting Process: Aroma Composition and Chemical Indices. Journal of Agricultural and Food Chemistry, vol (60), pg11283-11291.

[2]. Nwanya S. C., Okonkwo C. B. and Nwaoha I. E. (2014). Effect of blend ratio on thermo- physical and sensory characteristics of composite wheat, cassava and soy bread. Nigerian Journal of Technology (NIJOTECH). Vol. 33. No. 2, April pp. 184-191.

[3]. Fellows, P., 2009. Food Processing Technology: Principles and Practice ( $3^{\text {rd }}$ Ed.). Woodhead Publishing Series, pg. 928.

[4]. Manguiat, L. and Fang, T., 2013. Microbiological Quality of Chicken- and Pork-Based StreetVended Foods from Taichung, Taiwan, and Laguna, Philippines. Food Microbiology vol (36), pg57-62.

[5]. Onwukeme, V. I., Obijiofor, O. C. and Tabugbo, I. B., 2016. Comparative Study on the Influence of Grilling Height on the Concentration of Polycyclic Aromatic Hydrocarbons (PAHS) and Some Toxic Metals in Grilled Foods, International Journal of Science and Technology Volume 5 pg425-432 
[6]. Adisa Y.A., 2018. Design and Development of a Charcoal Fired Plantain (Musa Paradisiaca) Roasting Machine. Thesis of Mechanical Engineering (M.Sc.), Department of Mechanical Engineering, Ahmadu Bello University, Zaria, Nigeria

[7]. Ezekiel, O.O., Akinoso, R., and Olaoye, D.J., 2012. Design, fabrication and evaluation of a plantain roaster. Journal of Nigerian Institute of Food Science and Technology Vol 30(1), pg131 - 138.

[8]. Adegbola A.A., Adogbeji O.V, Abiodun O.I and Olaoluwa S., 2012. Design and Construction of a domestic basic oven. International Journal of Science, Technology and Society, 2(5):161164.

[9]. Oke P.K. (2013) Development of a MultiPurpose Roasting Machine. The Pacific Journal of Science and Technology, vol 14(2), pg48-53

[10]. Olayinka O.A and Adegboye F.A., 2017. Development of a Manually Operated MultiPurpose Roasting Machine. British Journal of Applied Science and Technology vol 20(1) pg17,

[11]. Mato C. N and Onajin-Obembe. B., 2014. Charcoal-roasted plantain and fish vendors in Port Harcourt: A Potential Anaesthetic High Risk Group, Southern African Journal of Anaesthesia. 14:6, 7-9,

[12]. Ilori TA, Raji AO, Adejumo AO, Kilanko O., 2014. Development and performance evaluation of a maize roaster. International Journal of Science, Technology and Society, 2(5) pg161-164.

[13]. Sangay L.H., 2009. Development and Evaluation of a Corn-Roasting Machine for a Small Scale Production of Cornflake (Tengma) in Bhutan. Department of Agricultural Engineering, University of Kasetsart, Thailand.
Thailand International Development Cooperation Agency (TICA), Thailand, p34-40

[14]. Wasiu. A.L (2015). Studies of Maize (Zea mays) Production under Different Cultivation Methods as a Practicum for Senior Secondary School Students, International Journal of Agriculture and Forestry, 5(1): pg38-44.

[15]. Karthik, S.K., Mahesh, T., Sumanth, B. and Tanmay, M., 2017. Study of Physical and Engineering Properties of Corn (Zea mays). Bulletin of Environment, Pharmacology and Life Sciences (Bull. Env. Pharmacol. Life Sci.,) Vol (6) pg. 404-409

[16]. Morey, R. V. and Gustafson, R. J., 1978. Fan Management for Ambient Drying Systems. J. $A S A E$, 78: 3003.

[17]. TCM, 2018. Technical Manual Report on Chain. Available online at www.tsubaki.co

[18]. Rajput, R K., 2004. Heat and Mass Transfer. Chand and Company Limited, New Delhi.

[19]. Khurmi, R.S K and Gupta J.K., 2008. A textbook of mechanic design, New Delhi' Eurasia publishing house.

[20]. Hall A., Holowenko A.R., and Laughlin H. G., 2006. Schaums Outline of Theory and Problems of Machine Design. Tata McGraw-Hill Publishing Company Limited, New Delhi.

[21]. Spotts M. F., Shoup T. E. and Hornberger L. E., 2004. Design of Machine Elements, Vol 2, Pearson/Prentice Hall.

[22]. Soheili M.A., Keyhani, A., Abbaspoursani, K. and Akram, A., 2006. Design of a Forced Convection Solar Dryer for Leafy Vegetables and Evaluation of the Solar Energy Collector Performance. J. Agric. Eng. Res., 7(27), pg147163. 